Forthcoming American Journal of Political Science

Race, Bureaucratic Discretion, and the Implementation of Welfare Reform

\author{
Lael R. Keiser \\ Associate Professor \\ 113 Professional Building \\ Department of Political Science and Truman School of Public Affairs \\ University of Missouri, Columbia \\ e-mail: keiserl@missouri.edu \\ Peter Mueser \\ Associate Professor \\ 118 Professional Building \\ Department of Economics \\ University of Missouri, Columbia \\ e-mail: mueserp@missouri.edu \\ Seung-Whan Choi \\ Visiting Assistant Professor \\ 113 Professional Building \\ Department of Political Science \\ University of Missouri, Columbia \\ e-mail: choiseu@missouri.edu
}

June 2003 


\title{
Race, Bureaucratic Discretion, and the Implementation of Welfare Reform
}

\begin{abstract}
This paper explores the impact of the race of individual clients and of the local racial context on the implementation of sanctions for recipients of Temporary Assistance for Needy Families (TANF) in a Midwestern state. We find that although nonwhites are sanctioned at lower rates than whites overall, nonwhites are sanctioned more compared to whites in each local area. This paradox occurs because nonwhites tend to live in areas with lower sanction rates. Consistent with the literature on race and policy, we find that sanction rates increase as the nonwhite population increases until a threshold is reached where nonwhites gain political power.
\end{abstract}


In the United States, racial politics shapes public policy (Hero 1998)—especially social welfare policy. How race influences public policy is determined by the administrative structures that policymakers adopt for implementation (Lieberman 1998). One important administrative structure that influences the experiences of racial minorities in the welfare state is the level of devolution of administrative control between the national government and state and local governments (Lieberman and Lapinski 2001). Concern exists that higher levels of devolution and bureaucratic discretion will lead to a loss of equity in the treatment of minorities participating in government programs (McConnell 1966; Key 1949). The historical treatment of minorities in highly localized welfare programs prior to the 1970s suggests that this concern is well justified (Katz 1989; Lieberman 1998; Piven and Cloward 1977). State and local governments have gained more discretion in the implementation of welfare policies during the 1990s with waivers granted by the federal government and with the passage of federal welfare reform in 1996, but little attention has been paid to the impact of race on the implementation of these welfare reforms. ${ }^{1}$

Race may affect the treatment of welfare clients in two ways. First, the race of an individual client may affect the interaction the client has with street-level bureaucrats. Street-level bureaucrats may have a tendency to favor clients who resemble themselves and discriminate against those from different class or racial backgrounds (Lipsky 1980). Second, the racial context in which policy implementation takes place may also impact how clients experience public programs. Race, in the aggregate, influences the structure that public policy takes, gives it substance and may even be a better predictor of state politics and policies than political culture (Hero 1998).

We do two things in this project. First, we explore whether minority clients of Temporary Assistance for Needy Families (TANF) fare less well than non-minorities in the implementation of one aspect of welfare reform — the sanctioning of benefits in response to clients' failure to follow the

\footnotetext{
${ }^{1}$ Exceptions include Soss et al. (2001) and Fording (2003).
} 
rules of the program. More specifically, we examine whether the race of a client influences the likelihood that she will be sanctioned in the state of Missouri for the year 1998. Second, we examine how the political and economic characteristics of the county in which a client is sanctioned, including its racial composition, influences the implementation of sanctions.

A small number of studies provide detailed analyses of the recipient attributes and circumstances associated with TANF sanctions. Chang et al. (2001) examine sanctions for failure to cooperate in obtaining child support in 20 central Illinois counties; Kahil et al. (2002) examine sanctions in a Michigan county; and Cherlin et al. (2002) look at sanctions in Boston, Chicago and San Antonio. Reviews of sanction policies across states and of related studies can be found in Goldberg and Schott (2000), and Pavetti and Bloom (2001). Although these studies provide information about how individual level characteristics influence sanctions, none of them explore how individual level characteristics and the geographic location of clients interact to impact the implementation of sanctions.

\section{State Sanction Policy}

In 1994, Missouri undertook major reform of Aid to Families with Dependent Children (AFDC) when it passed House Bill 1547, implemented in 1995 with federal approval of a statewide waiver. The reforms required each nonexempt recipient to enter into a "self-sufficiency pact" leading to self-supporting employment within two years, raised allowable asset levels, increased efforts to establish paternity, instituted changes in the JOBS program, including establishing a wage supplementation program, and instituted other program changes. Federal welfare reform replaced AFDC with Temporary Assistance for Needy Families (TANF) at the end of 1996, but associated policy changes were relatively small, since state reform had already occurred, and no state legislation was passed at that time.

Most importantly for our purposes, the state's reform legislation provided for sanctions, a 
reduction in the case grant for recipients failing to meet training, work, or other requirements. Prior to 1994, in keeping with federal AFDC regulations, very few sanctions were applied. By the end of 1995 , however, the number had increased to about 1 percent of the caseload, growing steadily to well over 10 percent in 1998.

Case managers decide when to impose a sanction. During our study, over 80 percent of sanctions in effect were imposed because of failure to conform to job training program requirements, so an important source of case manager discretion is in the application of rules that exempt clients from job training. Although some rules allow little latitude, such as those providing exemptions for recipients in the third trimester of pregnancy or with children under the age of 12 months, other rules appear to be open to interpretation. Exemptions are permitted for claimants facing domestic violence, temporary disability, or difficulty obtaining childcare.

Through October 1998, the sanctioned caretaker's benefit was subtracted from the family grant. After October 1998, the entire family grant was reduced by 25 percent. The duration of the sanction differs by the sanction history of the case. For a recipient's first sanction, the sanction is lifted as soon as the recipient starts to cooperate. For the second, however, the recipient's benefit is normally reduced for at least three months and continues until the case manager believes the recipient is moving toward compliance. Third and later sanctions must normally last for at least six months. ${ }^{2}$ Although the state agency collects data on how many clients are sanctioned, the central office does not monitor the use of sanctions in any systematic way. The only time the central office

\footnotetext{
${ }^{2}$ In October of 1998 Missouri issued regulations reducing the circumstances under which sanctions could be imposed and specifying that caseworkers meet with recipients prior to imposing sanctions. The number of new sanctions declined dramatically in November and December as a result. This change implies that our results are not directly applicable to the subsequent Missouri sanction policy.
} 
becomes involved in the process is if a client appeals the sanction, which is uncommon.

Sanctions in Missouri provide a good case study for examining the role that race plays in affecting policy implementation. First, individual-level data exist on the race of clients, whether they have been sanctioned, and the length of the sanction. This allows us to explore whether the race of a client has an impact on how that client is treated. Such individual data have been lacking in other research on race and welfare and is needed to know the extent to which street-level bureaucrats treat whites and blacks differently (Lieberman 1998, 130). Second, information on county of residence is available for all recipients. Counties are natural units to use in the study of welfare policy. For all but the largest counties, there is one local office that serves all recipients in the county, and where there is more than one, the offices are administered centrally within the county. Third, Missouri's sanction policy is administratively similar to other states in the level of discretion given to street-level bureaucrats. This makes the results more generalizable to other states. In most states, as in Missouri, caseworkers have primary responsibility for sanction decisions (United States General Accounting Office 2000). Like three-quarters of the states, Missouri only sanctions a portion of the family benefit for a first infraction. ${ }^{3}$

Although devolution of responsibility has assured much heterogeneity in the way that states implemented welfare reform, Missouri's system is broadly representative of the nation. Fender, McKernan and Bernstein (2001) show that Missouri is very similar to other states in terms of the financial incentives faced by recipients and in the institutional emphasis on moving recipients toward self-sufficiency. The industrial distribution of employment in Missouri corresponds closely to national figures. The demographic, racial and educational structure of the population mirrors that

\footnotetext{
${ }^{3}$ This penalty is the same for later sanctions, in contrast to nearly two-thirds of the states, which ultimately apply "whole case" sanctions (Rector and Youssef 1999; United States General
} Accounting Office 2000). 
of the country as well, with the notable exception that Missouri has fewer Hispanics. ${ }^{4}$ In contrast to some states, the basic program rules, including those about imposition of sanctions, are specified by the central state agency. If we observe differences across local areas in Missouri, this implies that local factors can be important even when central control is relatively strong. One might expect to find even larger differences within states with greater local autonomy.

In what follows, we generate and empirically test hypotheses about why the likelihood of sanctions varies by race across TANF recipients and across geographic areas.

\section{Hypotheses}

\section{Explaining Variation in the Likelihood of Being Sanctioned Across Individuals}

Race

Research in political science suggests several hypotheses concerning the implementation of sanction policy. The first is that race is the basis for direct discrimination, implying that street-level bureaucrats treat minority clients differently from non-minority clients due to racist attitudes and racial stereotyping (Lipsky 1980). Some empirical support exists for this contention. Davis and Proctor (1989) find that white social workers prefer working with white clients and have preconceived ideas and attitudes about minorities. Furthermore, surveys of welfare recipients find that black welfare recipients report lower levels of caseworker support for transportation assistance and for formal education than do white welfare recipients (Gooden 1998) and higher incidences of sanctions (Kahil et al. 2002). Under the direct discrimination hypothesis, a minority client will face a greater chance of sanction than an otherwise identical non-minority client.

\section{Professional Norms}

In addition to the impact of race, bureaucratic decisions may be influenced by professional values. While many scholars fear bureaucratic discretion because of the potential loss in equity in

\footnotetext{
${ }^{4}$ Carrington et al. (2002) compare Missouri's welfare reforms and its economy with the nation.
} 
policy implementation (Handler 1986; Lipsky 1980), others argue that bureaucrats follow professional norms in using their discretion and that they value equity (Goodsell 1981). According to the professional norms hypothesis, the likelihood of sanctions should correlate with the likelihood that a client will violate the rules. The professional values hypothesis suggests that several factors that indicate how much difficulty a recipient will have engaging in work activity and factors that make it more likely a recipient will be exempt should predict whether a sanction occurs and the length of the sanction. Individuals with lower levels of education and with less extensive prior work experience should have more difficulty complying with the work requirements. In our analysis below, to control for the likelihood of violating program rules or being exempted, the number of children a client has, the youngest child's age, the length of the welfare spell, and the client's education and work history are controlled.

Explaining Variation in Sanctions Across Counties

Case managers do not sanction individual clients in a vacuum. We expect that the characteristics of the population in the local geographic area - especially its racial diversity — as well as the local political environment will affect how sanction policy is implemented. Race

Hero (1998) points out that racial diversity of the population affects the characteristics of public programs and the distributional consequences of policy. Racial diversity is linked to infant mortality rates, minority graduation rates, incarceration rates and the size of the AFDC caseload (Hero 1998; Lieberman 1998). The conclusion of this research is that the racial context in which policy is implemented plays a role in determining policy outputs. To examine the impact of the racial context on sanction policy, we examine variation in the overall sanction rate across counties.

Racial diversity may affect public policy in different ways. Geographic proximity to large minority populations may increase feelings of racial threat among whites (Fossett and Kiecolt 1989; 
Giles 1977; Giles and Buckner 1993; Giles and Evans 1986; Key 1949; Stein et al. 2000; Wright 1977; but see Hero 1998; Voss 1996). Racial threat leads to a decrease in support of policies that are viewed as serving minorities (Kinder and Mendelberg 1995; Stein et al. 2000). Furthermore, attitudes towards public programs are shaped by the social construction of the population the public sees the program as targeting (Schneider and Ingram 1993). When the public perceives that the target population of social welfare policies are minorities, support for those programs decreases and programs become less generous (Katz 1989; Quadagno 1994). Accordingly, counties with larger minority populations should have more punitive administrative practices than those with smaller minority populations.

Past research supports the view that racial politics play a large role in determining the structure of social welfare policy (Nelson 1990; Mink 1990). A negative relationship exists between the percent minority in the population and state AFDC spending (Brown 1995; Hero 1998; Radcliff and Saiz 1994; Howard 1999; Orr 1976; Wright 1977). States for which the AFDC caseload had a larger black proportion were more likely to adopt restrictive waivers prior to welfare reform (Fording 2003). Furthermore, Soss et al. (2001) find that states with a higher percent of minority TANF clients are more likely to adopt more restrictive TANF policies such as stronger sanctions, stricter time limits and family caps than states with lower percent of minority TANF clients.

Unlike the focus of the above research, we are concerned with the impact of the racial context on policy implementation rather than on policy adoption. The racial composition of the local area should also influence policy implementation because it is an essential part of the political environment in which street-level bureaucracies exist. Policy implementation is influenced by the local political environment even when local officials have no authority over policy adoption (Keiser 2001; Weissert 1994). First of all, community leaders may directly influence street-level 
bureaucracies by interacting with officials in the bureaucracies. Weissert (1994) found that in some Michigan counties, directors of welfare offices had high levels of interactions with local community groups and our informal observations of directors in Missouri reveal a similar pattern. ${ }^{5}$ Second, local community groups also facilitate relationships between clients and street-level bureaucracies by providing clients with information and acting as advocates on the behalf of clients (Soss 2000).

Third, street-level bureaucrats may live in the communities in which they work making it more likely that their personal values will be affected by the racial context of where they live. Therefore, racial diversity may influence the structure of sanction policy in local offices. Areas with high percentages of nonwhites in the TANF caseload should have more restrictive and punitive practices for implementing sanctions and the overall sanction rate should be highest in such areas. Insofar as this hypothesis is supported, both whites and nonwhites in areas with large nonwhite populations experience policy consequences due to racial politics.

\section{Political Environment}

In addition to the racial composition of the population, the political environment may affect how street-level bureaucrats use their discretion in sanctioning clients. A rich literature exists showing that policy implementation is affected by the political environment (Wood and Waterman 1994; Scholz and Wei 1986). Historically welfare policy is a partisan issue, with Republicans favoring more restrictions and Democrats favoring more liberal policies (Rom 1999). Partisanship may affect implementation through two mechanisms. First, street-level bureaucrats in Democratic areas may be more likely to be Democrats themselves or be influenced by the ideology of the community and, therefore, less likely to sanction. Second, local elected officials may exert some

\footnotetext{
${ }^{5}$ The first two authors have interviewed numerous state officials as part of a study sponsored by the Rockefeller Institute examining the impacts of federal and state welfare reform on social service provision. Conclusions of this research appear in Fossett, et al. (2002).
} 
pressure on street-level bureaucrats to interpret policy in line with their partisanship. Regardless of the mechanism, we should expect that clients living in areas with more Democrats should be less likely to be sanctioned than clients living in Republican-dominated areas.

The size of the TANF caseload may create political pressure on street-level bureaucrats. In the 1990s high levels of political pressure existed to reduce welfare caseloads, and both Democrats and Republicans pledged to reduce welfare rolls. States with high caseloads have an incentive to adopt conservative welfare policies (Peterson and Rom 1990) because one way to reduce demand on public programs is to interpret program rules strictly (Lipsky 1980; Prottas 1979). Officials in the state office may be more likely to exert caseload reduction pressure on street-level bureaucrats in county offices with high welfare caseloads than on county offices with lower caseloads. We should expect, therefore, that clients in counties with high welfare participation will be more likely to be sanctioned than clients in counties with lower welfare participation.

Although bureaucrats may use their discretion to the detriment of clients, they may also use their discretion to be more responsive to the needs and opportunities of their clients (Goodsell 1981). Street-level bureaucrats may take into account the ability of clients to participate in the work requirements, for example considering the labor market when deciding on whether to sanction. We may therefore expect that the unemployment rate would be negatively related to the sanction rate while population size should be positively related.

\section{Interaction of Race and Politics}

Research suggests that race in the aggregate should interact with the political environment to influence sanction rates. Above a critical point, increases in minority population lead to increases in minority political power, which translates into policies that are more favorable to minorities. Consequently areas with intermediate levels of minority populations should have the least favorable policies, since the minority population will imply a threat but not be large enough to gain political 
power (Fording 1997; Keech 1968). Fording (1997) finds support for this non-linear relationship in his study of the link between minority population, insurgency and state AFDC growth. We hypothesize that the political power of minorities will influence policy implementation in a way that is analogous to its influence on policy adoption, inducing a curvilinear relationship between minority population and sanction rates.

The political power of minorities should influence policy implementation in three ways. First, increases in minority political power should increase the political power of community groups who act on behalf of minorities. Second, elected officials will be more likely to exert political influence on behalf of minorities when minorities have high levels of political power. Third, bureaucracies in areas with high minority political power may feel more pressure to hire more minorities as supervisors and caseworkers. In contrast, areas with sizable minority populations that fall below the threshold that translates into political power are likely to have lower community support for programs that have been identified as assisting minorities (Quadagno 1994), resulting in more stringent program implementation.

These arguments suggest that street-level bureaucrats and supervisors in areas with high concentrations of minorities and minority political power should feel greater political pressure to implement sanctions in a more lenient way than those in areas with sizable minority populations but low minority political power. We expect that counties with the smallest and largest minority shares will have the lowest levels of sanctions and the lowest disparity between minorities and nonminority sanction rates, while counties with moderate minority shares will have the highest levels of sanctions and the greatest disparity between minority and non-minority sanction rates.

In Missouri, even though policies regarding sanctions are determined centrally, in practice the caseworker has substantial autonomy. As noted above, there are many bases on which recipients can be exempted from work requirements, and many clearly are matters of interpretation. 
A caseworker who wished to apply rules in such a way as to benefits certain clients-whether consciously or not—would have latitude to do so. Even intentional violations of explicit rules by caseworkers might not be detected, as only a small proportion of case decisions is reviewed by supervisors. This is not to say that local office managers have no impact on rule implementation. Although rules drafted by the state office are available to caseworkers in written form, local offices provide substantial interpretation and hands-on support for caseworkers. The views of an office or regional manager are expected to influence both the training caseworkers receive and on-going directives. In short, the administrative structure clearly allows for the impacts of personal and political forces on sanction implementation, whether these work through authority channels in the local office or through social networks of individual caseworkers.

\section{The Data}

The data on welfare participation and sanctions come from monthly extracts of administrative files. These data can be aggregated to the county level so we can explore variation in sanctioning across counties in addition to variation across individual recipients. We limit consideration to females coded as payees receiving cash benefits as part of the TANF program where the payee was the parent or equivalent. ${ }^{6}$ The overwhelming majority of these are single parents, but we also include the very small number in two parent families enrolled in the successor to the AFDC-Unemployment Parent program. Our focus is on the 12 months of 1998, the second

\footnotetext{
${ }^{6}$ We omit "child only" case, where the payee is not a parent or an individual who has direct legal responsibility for the children but receives payment on their behalf. Such payees are not subject to training or employment requirements and normally do not face sanctions.

${ }^{7}$ During 1998, the percent black in the TANF caseload increased from 51.9 percent to 55.4 percent, while the proportion coded in all other nonwhite race categories, including Hispanic, remained at 1.9 percent.
} 
year that TANF was in effect in the state.

The files include sanction status, length of the current spell of welfare, race, education, county, as well as the number of children and their ages. The racial classification identifies Hispanics as a racial category, and we have coded blacks, Hispanics, and other races as "nonwhite." Over 96 percent of those coded as nonwhite are black. ${ }^{7}$ In addition to information on TANF recipients, we have data collected by state agencies in Missouri and Kansas identifying earnings for all employment covered by their unemployment insurance systems. ${ }^{8}$ We have matched TANF payees with these records, providing information on earnings over the five years prior to 1998 .

Initial analyses showed that, during 1998, the chance that a case currently not facing a sanction is sanctioned in the following month is about 2 percent. Sanctions normally last for many months, with the chance that a sanction continues to a subsequent month at about 80 percent, for at least the first 10 months. The chance that the sanction is lifted in the following month is about 5-10 percent, whereas the chance that the recipient leaves welfare is $10-15$ percent. Clearly this supports the view that sanctions may be a tool that caseworkers can use to reduce the caseload. ${ }^{9}$

During the period of our study, over four-fifths of the sanctions in effect were for failure to abide by work training participation requirements. Slightly more than one in ten were imposed due to failure to cooperate with child support enforcement. Other infractions of the rules accounted for the remainder of sanctions. Failure to provide necessary documentation could cause a case to be dropped from the rolls, but it would not normally result in a sanction.

Table 1 considers rates of sanction by race and geographic area. The sample size is the total

\footnotetext{
${ }^{8}$ These data omit self-employment earnings and earnings in informal or undocumented jobs, for which there is no unemployment insurance coverage, as well as a small number of exempted jobs. However, the overwhelming majority of employment is included.

${ }^{9}$ Detailed survival analyses of sanctions are presented in Keiser, Mueser and Choi (2002).
} 
number of months of TANF receipt by all recipients during the year, so results are representative of the average monthly caseload. Overall, 16.3 percent of white recipient months are sanctioned whereas only 14.2 percent of nonwhite months are sanctioned, a difference of 2.1 percentage points. Based on this simple comparison, it would appear that whites are either more likely than nonwhites to engage in behavior that violates program rules or that they face discriminatory treatment. A closer examination of the data reveals, however, that the relationship between race and sanctions is more complicated.

(Table 1 about here)

The remainder of the table divides the state into seven areas. The St. Louis metropolitan area is divided into St. Louis City (a county equivalent unit), St. Louis County, and an area consisting of the remaining suburban counties. The Kansas City metropolitan area is divided into Jackson County (containing virtually all of Kansas City), and an area consisting of the suburban counties. Small metropolitan counties are those in the four smaller metropolitan areas, and, finally, all non-metropolitan counties in the state make up the last category.

Comparison across areas reveals substantial differences in sanction use. St. Louis City and St. Louis County, with rates around 10 percent, have appreciably lower rates of sanction than the other areas, with rates ranging from 16 to 23 percent. Interestingly, although whites are sanctioned more than non-whites overall, when we compare sanction rates within counties, the opposite pattern emerges. In every area, the sanction rate for nonwhites is above that for whites. The proportion of nonwhites facing sanctions is lower overall because nearly two-thirds of nonwhite recipients live in St. Louis City or St. Louis County, where sanction rates are very low, whereas only 14 percent of white recipients live there.

The disparity in sanction rates by race differs by site. For St. Louis County and the other suburban St. Louis counties, the difference is a half a percentage point or less. The largest 
differences are in the non-metropolitan counties and in Jackson County, where sanction rates for nonwhites are more than five percentage points higher than for whites.

The rightmost column of Table 1 provides the racial composition for the whole population in the geographic area. Although only about 16 percent of the state's population is nonwhite, there is much variation across these areas. St. Louis City has the largest share of nonwhites, at 57 percent, while the non-metropolitan counties have the smallest, at 7 percent. This table provides support for the view that the racial composition of an area has an impact on the implementation of sanction policy. The non-metropolitan counties, taken as a group, have higher sanction rates and greater differences in rates between whites and nonwhites than the other geographic divisions, consistent with the view that the small nonwhite population produces a policy that is less favorable to welfare recipients and nonwhites. On the other end of the scale, sanction rates for whites and nonwhites are much lower and the difference between them is small for St. Louis City, consistent with the high nonwhite proportion in the population.

The sanction statistics presented in Table 1 do not control for differences in the detailed characteristics of recipients. In the next section, we will consider whether the geographic racial differences in sanctions identified above are attributable to variation in the characteristics of recipients. County controls will also be introduced in order to explore the extent to which policies vary across finer geographic divisions. In the subsequent section, factors influencing decisions at the county level will be explored.

\section{The Individual Determinants of Sanction}

We use two dependent variables to capture sanction policy. The first is a dichotomous variable indicating whether a payee is sanctioned in a given month, corresponding to the sanction prevalence measure considered above. Since most individuals facing sanctions in a given month are in a sanction continuing from a prior month, this measure captures both prior and current policies. 
In addition, since many individuals leave welfare when they face sanctions, this measure may be influenced by the likelihood of leaving welfare. For example, if certain kinds of recipients are particularly likely to leave welfare when they face sanctions, such individuals will have lower rates of sanction according to this measure. Although the units of analysis are months that individuals are on welfare, in the reported analysis these units are weighted so that the total weight for each welfare recipient is unity.

The second sanction measure analyzed is initiation of a sanction. For an individual who is not subject to a sanction in a given month, this measure is coded one if that individual is sanctioned in the next month and zero if the individual continues to receive welfare and is not sanctioned. If the individual does not receive welfare in the following month, that observation is excluded from this analysis. This measure is a cleaner measure of sanction actions taken during 1998. The units of analysis are months of welfare receipt in which individuals are not currently sanctioned, and as above each month is weighted such that the total weight for a recipient is unity.

Table 2 provides coefficients for the binomial logit regressions predicting each sanction measure. A variety of individual characteristics are controlled, including age, length of the current welfare spell, number and age of children, education, employment history, and dummies for the seven geographic regions and for the 12 months. We experimented with a variety of functional forms to fully capture impacts. Results are largely as expected. Recipients more likely to face exemptions from participation in work or training programs (those with young children) and those expected to have less difficulty working or attending training (those with fewer children and higher educational levels) have lower sanction levels. Older recipients and those with higher prior earnings also are less likely to face sanctions, although the impact of prior work experience is complex, reflecting unmeasured factors associated with employment history. ${ }^{10}$

${ }^{10}$ A full discussion of the relationships identified here, along with a more detailed analysis of 
(Table 2 about here)

For the most part, the patterns of coefficients in the model predicting sanction in a given month (left panel) and those in the model predicting an initial sanction (right panel) are similar, although the impact of the length of the current welfare spell is an exception. Recipients in their first year of welfare are less likely than longer-term recipients to be facing a sanction in a given month, since those on welfare for short periods have had less time to be found in violation of the rules. In contrast, the right panel shows that those receiving welfare for longer periods are less likely to have a sanction spell begin at any one point in time.

The impact of race corresponds, at least roughly, to the pattern observed within the geographic areas identified in Table 1. Whites have appreciably lower rates of sanction even after all recipient characteristics are controlled. The coefficient in the left panel implies that for an individual with typical characteristics, the chance of facing a sanction is at least 23 percent lower if the person is white. The impact of race in predicting initiation of a sanction (right panel) implies the chance is 18 percent lower.

Six dummy variables control for seven parts of the state, and coefficients correspond to the differences identified in Table 1. Coefficients for St. Louis City and St. Louis County indicate that the likelihood of a sanction for an individual with given characteristics is less than half that for nonmetropolitan counties (the omitted category). Other differences are much smaller. The chance of sanctions is slightly lower in Jackson County than in the non-metropolitan counties, whereas it is somewhat higher in the Kansas City suburban counties and slightly higher in the small metropolitan counties. In the model that predicts initiation of a sanction (right panel), the pattern of coefficients is the same.

Since a primary focus of our analysis is sanction differences by race, we have fitted a model sanction patterns, is provided in Keiser, et al. (2002). 
that adds interaction effects by race to the models specified in Table 2 . The coefficients on these interaction terms, which are presented in Table 3, show how race impacts the likelihood of sanction in each of the areas of the state, controlling for individual characteristics. The coefficients are analogous to the coefficient for the race variable in the earlier regression, except that they capture the separate effects of race for each area.

(Table 3 about here)

Point estimates for the coefficients for these interaction terms indicate that, for the general sanction variable (left panel), whites are less likely to be sanctioned than are nonwhites in all areas, although the coefficients are statistically significant only for three of the areas. The differences are greatest in Jackson County and in the non-metropolitan counties. The difference is not statistically significant for the suburban Kansas City counties, where the small number of nonwhites inflates measurement error. The difference is slightly smaller but still substantial and statistically significant for St. Louis City. Other differences are smaller and not statistically significant. Estimated coefficients for the impact of race on the initiation of sanctions (right panel of Table 3) are less accurately estimated than those in the model predicting overall sanctions, but these coefficients also suggest that whites are sanctioned at lower levels than nonwhites. Statistical tests confirm that for either sanction measure, we can reject the hypothesis that the impact of race is the same in each of the seven regions.

\section{Explaining Variation in Sanction Policy}

\section{Sanction Prevalence}

The results discussed above show that counties differ in sanction rates and differ in the disparate treatment between whites and nonwhites. What explains this variation? In order to examine the determinants of geographic variation in sanction policy, we have estimated a model

paralleling that in Table 2 but with dummy variables for each of the 115 counties or equivalent units 
in Missouri. The estimated coefficients, which identify the level of sanctions or initiation of sanction in each county, are then taken as the dependent variable in a regression, where each of the counties is a unit in the analysis. ${ }^{11}$ Structuring the dependent variable in this manner allows us to control for the characteristics of the individuals who make up each county's caseload as we analyze variation in sanction rates across counties.

Our focus is on examining what county characteristics—especially those reflecting the political structure - are associated with sanctions. We consider six county characteristics: the percentage of the county population that is nonwhite, the percentage of county officials who identify with the Democratic Party ${ }^{12}$, the proportion of the vote cast for the Democratic candidate in the 1998 U.S. Senatorial election, the unemployment rate in the county, the average TANF caseload size as a percent of the county population, and the percentage of the TANF caseload that is nonwhite.

Since the sample is small, inclusion of multiple predictors in a single regression provides little information. ${ }^{13}$ Table 4 reports coefficients for each of the six county characteristics when it is

${ }^{11}$ Unfortunately the small number of minorities in many Missouri counties reduces the sample size to such an extent that meaningful analysis of the variation in the disparate treatment between whites and nonwhites is difficult. Although we ran such a model, none of the coefficient estimates reached statistical significance.

${ }^{12}$ The few county officials who are not identified with the Republican or Democratic parties are omitted from the tabulation.

${ }^{13}$ We fitted models with multiple variables, but the high correlation between variables inflated estimation errors to the point where results were not interpretable. Correlations between the percent nonwhite in the county population, the caseload as a proportion of the population, and the percent of the caseload nonwhite are over 0.6. The proportion in the population voting Democratic is 
entered as the sole predictor of the sanction measure in linear form, and then when it is entered in a quadratic form, that is, represented by both a linear and a square term. Limiting the analysis to models that consider only one county measures at a time does weaken our ability to distinguish the hypotheses of county differences in sanction rates. As mentioned above, however, the structure of the dependent variable controls for the individual-level characteristics of county recipients, which strengthens our tests.

\section{(Table 4 about here)}

As in the earlier models, we have two measures of sanction, the first referring to sanction in any month (the left panel) and the second the imposition of a sanction on a recipient who was not facing a sanction in the prior month (right panel). We have adjusted for the size of the standard error of coefficients to correct for heteroscedasticity due to the fact that the dependent variable is estimated for counties of very different sizes. ${ }^{14}$ Given that the hypotheses we consider here generally identify the sign of the coefficient, we report as statistically significant coefficients significant at the 0.05 level as indicated by a one-tailed test.

The left panel shows that there is little linear relationship between any of the measures and

correlated with these measures at levels over 0.4 .

${ }^{14}$ For models presented in Table 4, each of the observations is weighted by the term 1/[Var(E) $\left.\operatorname{Mean}\left(\mathrm{SE}^{2}\right)+\mathrm{SE}_{\mathrm{i}}^{2}\right]$, where $\operatorname{Var}(\mathrm{E})$ is the variance of the residual of the fitted equation (without weighting), $\mathrm{SE}_{\mathrm{i}}$ is the estimated standard error of the county $\mathrm{i}$ coefficient based on the logit, and Mean $\left(\mathrm{SE}^{2}\right)$ is the mean of the squares of $\mathrm{SE}_{\mathrm{i}}$ across all counties. This weighting will adjust for the impact of sampling error on coefficient estimates, based on the assumption that the residual for county $\mathrm{i}$ is given as $\mathrm{E}_{\mathrm{i}}^{2}=\mathrm{A}+\mathrm{B} \mathrm{SE}_{\mathrm{i}}^{2}$, where $\mathrm{B}=1$. An auxiliary regression showed that ordinary least squares estimates of $\mathrm{B}$ are, in fact, close to 1 . This is what theory predicts if sampling error is uncorrelated with county-specific error. 
the likelihood of a sanction but that the quadratic shows significant nonlinear effects for several measures posited to reflect political structure. The coefficients for the quadratic function of percent nonwhite indicate that proportion nonwhite increases the sanction rate at low levels of nonwhite populations but that when the share is over 16 percent the relationship reverses. A similar pattern holds for the percent voting Democratic in the Senatorial election, although the point of reversal occurs at about 43 percent. Percent of the caseload nonwhite shows a similar relationship. In each case the turnaround point occurs at a relatively low level. The basic structure of these results is very similar when the dependent variable is initiation of a sanction (right panel), with turnaround points corresponding approximately to those obtained with the broader sanction measure.

These results are consistent with the hypothesis that political processes tied to minority population influence sanction policy implementation in local areas. As the theory suggests, there is an increase in sanction as the minority population increases, until it reaches a critical point, after which it declines. Given the sample size and the association between our measures of minority population and political structure, it is not possible to distinguish their effects.

It is notable that there is no observed relationship between the unemployment rate in the county and the level of sanctions, as indicated by either the linear or the quadratic specifications. We also examined parallel models using linear and quadratic forms for the labor force participation rate and the employment rate, both calculated relative to population. None of the estimated coefficients were statistically significant.

It is natural to ask whether institutional or related factors may explain the observed relationships between race-related measures and county sanction. Workload differences across offices might well be related to racial composition, as could internal rules or procedures. Although such analysis might be useful in identifying mechanism, we do not believe that a finding that institutional structures were of importance would undermine our basic conclusions, since we expect 
such factors to be influenced by political forces tied to race.

The strength of the observed relationships should not be overstated. Figure 1 provides a scatterplot for counties showing variation in imposition of new sanctions by racial composition. The coefficient of the dummy variable in the logit regression, representing the likelihood of imposition of sanctions, is on the vertical axis, and the percent of the county's population that is nonwhite is on the horizontal axis. ${ }^{15}$ The area of the circles is proportional to county population.

(Figure 1 about here)

Differences between counties in imposition of sanctions are substantial. The maximum difference between the coefficients identifying sanction probabilities is about 3.5 units, implying that sanction rates differ by a ratio of about 20 . Of course, much of the variation in sanction levels observed for small counties may reflect variation that is idiosyncratic to particular individuals, since the number of welfare recipients is very small in these counties. If we consider a 2-unit range, in which all the large counties and most other counties fall, this implies a ratio of about 7 . It is clear that county differences are important, with St. Louis County and St. Louis City initiating sanctions at much lower rates than Jackson County and most other counties.

\section{Implications for Race and Public Policy}

As many scholars have argued, race is a central variable for understanding policy in the United States (Hero 1998; Key 1949). Our findings reveal that race plays a role, albeit a complicated one, in the implementation of welfare reform. Several of our findings are noteworthy and have implications for existing theory.

Most striking, although our findings suggest that TANF claimants are not disadvantaged by living in high minority population areas in terms of sanction policy, they do suggest that minorities

\footnotetext{
${ }^{15}$ For ease of interpretation, we have arbitrarily set the coefficient for St. Louis City equal to zero. Other measures indicate sanction rate relative to St. Louis.
} 
may face discrimination in the implementation of social services. Our analysis shows clearly that in any given county nonwhites are more likely to face sanctions than whites with similar demographic characteristics, work histories, family structures and welfare experience. Of course, it is impossible to quantify all of the variables that measure the likelihood that an individual client fails to comply with program rules. We cannot discern whether this disparity is due to the fact that street-level bureaucrats discriminate against minorities or that minorities have unmeasured characteristics that make them more likely to violate relevant rules. Clearly, however, the results show that the implementation of welfare reform is not race neutral. Minorities are either being treated differently than their white counterparts due to race or they are having more difficulty complying with the rules of the program than whites - difficulty that is not explained by educational attainment, work experience, number of children or length of time on welfare. At the individual level, race influences policy implementation.

Second, we find that, in the aggregate, white TANF recipients are more likely to face sanctions than are nonwhites due to the fact that they are more likely to live in areas with higher sanction rates. The difference is primarily due to the fact that nearly two-thirds of nonwhite recipients are in St. Louis City and St. Louis County, which have much lower sanction rates, as compared with only 14 percent of white recipients. At the other end of the spectrum, only 7 percent of nonwhite recipients are in the non-metropolitan counties, which have high sanction rates, as compared with nearly 45 percent of whites.

Our findings suggest that minority representation in the local population, once it has reached the threshold to give minorities political power, leads to policy implementation that is more lenient for all recipients. Our analyses show a curvilinear relationship between the proportion nonwhite and the level of sanctions controlling for the education, work and welfare history, family structure and race of a given individual recipient. Areas with almost no nonwhites have relatively low 
sanction rates. As the percentage of the nonwhite population increases, however, sanctions increase to a maximum level at about 10-20 percent nonwhite. Sanctions for counties with nonwhite proportions over this have progressively lower sanction levels.

We are not able to identify the exact process inducing this relation, since several dimensions of political structure are associated with the proportion nonwhite. It is suggestive, however, that the average level of sanctions increases as the proportion of the population voting Democratic grows until that proportion is slightly less than one-half. After that point, increasing Democratic voting is associated with lower levels of sanction. A similar pattern exists with the percent of the TANF caseload that is minority. ${ }^{16}$

Although we cannot separate out the effects of minority population, size of the minority caseload and minority political power in our statistical models, a comparison of the politics of two of the largest counties reveals that the area where minority population has translated into minority political power (St. Louis City) has lower sanction rates than an area that has a medium size minority population but less minority political power (Jackson County, containing Kansas City). The mayor of St. Louis is African American and historically minorities have had a strong voice in city politics (Stein 1991). In contrast, the political power of minorities in Jackson County is much more limited. Although we do not systematically test the relationship between racial context, minority political power and policy implementation, our findings suggest that political power mediates the influence of race on policy implementation as it does for policy adoption (see Fording

\footnotetext{
${ }^{16} \mathrm{We}$ are unable to test the effect of the size of the minority caseload on sanctions while controlling for the size of the minority population due to multicollinearity in the model. It is possible that, if we could add that control, the effect of minority caseload on sanctions would be linear, consistent with the finding by Soss et al. (2001) of a linear relationship between minority caseload and adoption of more stringent sanction policy.
} 
1997, 2003; Keech 1968).

\section{Conclusion}

Our results show a complex relationship between race and sanction policy under welfare reform and highlight the importance of the unit of analysis in research. Although, within any one county, minorities generally face higher levels of sanctions than do whites, even after controls for individual characteristics, in the aggregate, they are actually less likely to face sanctions. This result is due to the interaction of demographic structure and political process. Areas with the highest proportions of nonwhite population have low levels of sanctions, very likely reflecting minority political power. Since a large proportion of nonwhite welfare recipients live in such counties, in contrast to a relatively small proportion of white recipients, this difference overwhelms the higher rates of sanction faced by nonwhites within any given county. 


\section{References}

Brown, Robert D. 1995. "Party Cleavages and Welfare Effort in the American States." American Political Science Review 89 (1): 23-33.

Carrington, William J., Peter Mueser and Kenneth R. Troske. 2002. "The Impact of Welfare Reform on Leaver Characteristics, Employment and Recidivism.” University of Missouri Working Paper.

Chang, Yunhee, Andrea H. Beller and Elizabeth J. Powers. 2001. "Who Gets Sanctioned Under Welfare Reform? Evidence from Child Support Enforcement in Illinois.” Family Relations and Human Development/Family Economics and Resource Management Biennial 4: 53-61.

Cherlin, Andrew J, Karen Bogen, James M. Quane and Linda Burton. 2002. "Operating within the Rules: Welfare Recipients' Experiences with Sanctions and Case Closings.” Social Service Review 3: 387-405.

Davis, Larry E. and Enola K. Proctor. 1989. Race, Gender, and Class: Guidelines for Practice with Individuals, Families, and Groups. Englewood Cliffs, NJ: Prentice Hall.

Fender, Lynne, Singe-Mary McKernan and Jen Bernstein. 2001. "Taming the Beast: Categorizing Welfare Policies for Use in Research A Typology of Welfare Policies Affecting Recipient Job Entry.” Unpublished paper. Washington, DC: Urban Institute.

Fording, Richard C. 1997. “The Conditional Effect of Violence as a Political Tactic: Mass Insurgency, Welfare Generosity, and Electoral Context in the American States.” American Journal of Political Science 41 (1): 1-29.

Fording, Richard C. 2003. "Laboratories of Democracy or Symbolic Politics? The Racial Origins of Welfare Reform." In Sanford F. Schram et al. Ed. Race and the Politics of Welfare Reform. Ann Arbor, MI: University of Michigan Press.

Fossett, James, Thomas Gais and Frank Thompson. 2002. "New Systems of Social Programs? 
First Impressions from Field Research on Local Implementation of Health Care, Food Stamps, and TANF." Paper presented at meetings of the Association for Public Policy and Management.

Fossett, Mark and K. Jill Kiecolt. 1989. "Relative Size of Minority Populations and White Racial Attitudes." Social Science Quarterly 70: 820-835.

Giles, Michael and Arthur S. Evans. 1986. "Power Approach to Inter-Group Hostility.” Journal of Conflict Resolution 30 (3): 469-486.

Giles, Michael and Melaine Buckner. 1993. "David Duke and Black Threat: An Old Hypothesis Revisited." Journal of Politics 55 (3): 702-713.

Giles, Michael. 1977. "Percent Black and Racial Hostility: An Old Assumption Re-examined." Social Science Quarterly 58: 848-865.

Goldberg, Heidi and Liz Schott. 2000. A Compliance-Oriented Approach to Sanctions in State and County TANF Programs. Washington, DC: Center on Budget and Policy Priorities.

Gooden, Susan T. 1998. “All Things Not Being Equal: Differences in Caseworker Support Toward Black and White Welfare Clients." Harvard Journal of African American Public Policy 4: 23-33.

Goodsell, Charles T. 1981. "Looking Again at Human Service Bureaucracy." Journal of Politics 43 (1): 763-778.

Handler, Joel F. 1986. The Conditions of Discretion: Autonomy, Community, Bureaucracy. New York: Russell Sage Foundation.

Hero, Rodney E. 1998. Faces of Inequality: Social Diversity in American Politics. Oxford, England: Oxford University Press.

Howard, Christopher. 1999. “The American Welfare State, or States?” Political Research Quarterly 
52 (2): 421-442.

Kahil, Ariel, Kristin S. Seefeldt and Hui-chen Wang. 2002. "Sanctions and Material Hardship under TANF." Social Service Review 4: 642-662.

Katz, Michael B. 1989. The Undeserving Poor: From the War on Poverty to the War on Welfare. New York: Pantheon.

Keech, William R. 1968. The Impact of Negro Voting. Chicago, IL: Rand McNally \& Company. Keiser, Lael R. 2001. "Street-Level Bureaucrats, Administrative Power and the Manipulation of Federal Social Security Disability Programs.” State Politics and Policy Quarterly 1(2): 144164.

Keiser, Lael R., Peter Mueser and Seung-Whan Choi. 2002. "The Impositions of Sanctions under Welfare Reform.” Unpublished manuscript.

Key, V.O., Jr. 1949. Southern Politics in State and Nation. New York: Alfred A. Knopf.

Kinder, Donald R. and Tali Mendelberg. 1995. "Cracks in American Apartheid: The Political Impact of Prejudice among Desegregated Whites.” Journal of Politics 57 (2): 402-424.

Lieberman, Robert C. 1998. Shifting the Color Line: Race and the American Welfare State. Cambridge, MA: Harvard University Press.

Lieberman, Robert C. and John S. Lapinski. 2001. "American Federalism, Race, and the Administration of Welfare.” British Journal of Political Science 31 (1): 303-329.

Lipsky, Michael. 1980. Street Level Bureaucracy: Dilemmas of the Individual in Public Services. New York: Russell Sage Foundation.

McConnell, Grant. 1966. Private Power and American Democracy. New York: Alfred A. Knopf. Mink, Gwendolyn. 1990. "The Lady and the Tramp: Gender, Race, and the Origins of the American Welfare State.” In Linda Gordon. Ed. Women, the State, and Welfare. Madison, WI: University of Wisconsin Press. 
Nelson, Barbara J. 1990. “The Origins of the Two-Channel Welfare State: Workmen’s

Compensation and Mothers' Aid." In Linda Gordon. Ed. Women, the State, and Welfare. Madison, WI: University of Wisconsin Press.

Orr, Larry L. 1976. "Income Transfers as a Public Good: An Application to AFDC.” American Economic Review 66 (3): 359-371.

Pavetti, LaDonna and Dan Bloom. 2001. "State Sanctions and Time Limits." In Rebecca M. Blank and Ron Haskins. Eds. Washington, DC: Brookings Institution Press.

Peterson, Paul E. and Mark C. Rom. 1990. Welfare Magnets: A New Case for a National Standard. Washinton, DC: Brookings Institution.

Piven, Frances Fox and Richard A. Cloward. 1977. Regulating the Poor. New York: Vintage Books.

Prottas, Jeffrey Manditch. 1979. People-Processing: The Street-Level Bureaucrat in Public Service Bureaucracies. Lexington, MA: Lexington Books.

Quadagno, Jill. 1994. The Color of Welfare: How Racism Undermined the War on Poverty. New Work: Oxford University Press.

Radcliff, Benjamin and Martin Saiz. 1994. "Race, Turnout, and Public Policy in the American States," Political Research Quarterly 48 (4): 775-794.

Rector, Robert and Sarah Youssef. 1999. “The Determinants of Welfare Caseload Decline.” Report No. 99-04. Washington, DC: The Heritage Center for Data Analysis, Heritage Foundation. Rom, Mark C. 1999. “Transforming State Health and Welfare Programs.” In Virginia Gray and Herbert Jacobs. Eds. Politics in the American States. Washington DC: CQ Press.

Schneider, Anne Larason and Helen Ingram. 1993. "Social Constructions and Target Populations: Implications for Politics and Policy." American Political Science Review 87 (2): 334-347. Scholz, John T. and Feng Heng Wei. 1986. "Regulatory Enforcement in a Federalist System.” 
American Political Science Review 80 (4): 1249-1270.

Soss, Joe, Sanford F. Schram, Thomas P. Vartanian and Erin O'Brien. 2001. "Setting the Terms of Relief: Explaining State Policy Choices in the Devolution Revolution.” American Journal of Political Science 45 (2): 378-395.

Soss, Joe. 2000. Unwanted Claims: The Politics of Participation in the US Welfare System. University of Michigan Press.

Stein, Lana. 1991. Holding Bureaucrats Accountable: Politicians and Professionals in St. Louis. Tuscaloosa: University of Alabama Press.

Stein, Robert M., Stephanie Shirley Post and Allison L. Rinden. 2000. "Reconciling Context and Contact Effects on Racial Attitudes.” Political Research Quarterly 53 (2): 285-303.

United States General Accounting Office. 2000. Welfare Reform: State Sanction Policies and Number of Families Affected. Washington, DC: HEHS-00-44.

Voss, Stephen D. 1996. "Beyond Racial Threat: Failure of an Old Hypothesis in the New South." Journal of Politics 58 (4): 1156-1170.

Weissert, Carol S. 1994. "Beyond the Organization: The Influence of Community and Personal Values on Street-Level Bureaucrats’ Responsiveness.” Journal of Public Administration Research and Theory 4(2): 225-254.

Wood, B. Dan and Richard Waterman. 1994. Bureaucratic Dynamics: The Role of a Bureaucracy in a Democracy. Boulder, CO: Westview Press.

Wright, Gerald C., Jr. 1977. "Racism and Welfare Policy in America." Social Science Quarterly 57:718-30. 
TABLE 1

Proportion of 1998 TANF Recipients Subject to Sanctions by Race and Proportion Nonwhite in Total Population

\begin{tabular}{|c|c|c|c|c|c|c|}
\hline & \multicolumn{2}{|c|}{$\begin{array}{c}\text { Months of } \\
\text { Welfare Receipt } \\
\end{array}$} & \multicolumn{3}{|c|}{ Percent Sanctioned } & \multirow{2}{*}{$\begin{array}{l}\text { Population } \\
\text { Proportion } \\
\text { Nonwhite }\end{array}$} \\
\hline & White & Nonwhite & White & Nonwhite & Difference & \\
\hline Missouri & 215,635 & 270,693 & $16.3 \%$ & $14.2 \%$ & $2.1 \%$ & $16 \%$ \\
\hline St. Louis City & 14,636 & 118,987 & $9.0 \%$ & $10.8 \%$ & $-1.8 \%$ & $57 \%$ \\
\hline St. Louis County & 15,803 & 58,575 & $9.3 \%$ & $9.8 \%$ & $-0.4 \%$ & $24 \%$ \\
\hline Suburban St. Louis counties & 22,298 & 2,655 & $18.5 \%$ & $18.9 \%$ & $-0.4 \%$ & $5 \%$ \\
\hline Jackson County & 23,934 & 63,062 & $15.9 \%$ & $21.0 \%$ & $-5.1 \%$ & $32 \%$ \\
\hline Suburban Kansas City counties & 9,530 & 1,116 & $15.9 \%$ & $18.7 \%$ & $-2.8 \%$ & $8 \%$ \\
\hline Small metropolitan counties & 32,832 & 7,304 & $17.9 \%$ & $21.0 \%$ & $-3.1 \%$ & $9 \%$ \\
\hline Non-metropolitan counties & 96,602 & 18,994 & $17.7 \%$ & $22.9 \%$ & $-5.2 \%$ & $7 \%$ \\
\hline
\end{tabular}

Notes: Percent sanctioned is the proportion of all months of welfare recipiency for which sanctions are in force. Population proportion nonwhite is based on the 2000 U.S. Census, and it combines answers to race and Hispanic origin questions to match the welfare recipient coding, which classifies Hispanics as nonwhites. 
TABLE 2

Binomial Logit Predicting Sanction and Initiation of Sanction

\begin{tabular}{|c|c|c|c|c|}
\hline \multirow[b]{2}{*}{ Independent Variables } & \multicolumn{2}{|c|}{ Sanction } & \multicolumn{2}{|c|}{ Initiation of Sanction } \\
\hline & Coefficient & $\begin{array}{c}\text { Standard } \\
\text { Error }\end{array}$ & Coefficient & $\begin{array}{c}\text { Standard } \\
\text { Error }\end{array}$ \\
\hline Intercept & $-0.854 *$ & 0.123 & $-0.922 *$ & 0.199 \\
\hline White & $-0.296 *$ & 0.032 & $-0.204 *$ & 0.053 \\
\hline Age & $-0.030 *$ & 0.002 & $-0.031 *$ & 0.004 \\
\hline Welfare spell just beginning & $-2.127 *$ & 0.092 & $0.227 *$ & 0.057 \\
\hline On welfare 1 month, less than 1 year (omitted) & - & - & - & - \\
\hline On welfare 1 year or more, less than 3 years & $0.472 *$ & 0.031 & $-0.370 *$ & 0.056 \\
\hline On welfare 3 years or more, less than 5 years & $0.328 *$ & 0.041 & $-0.550 *$ & 0.080 \\
\hline On welfare 5 years or more, less than 10 years & $0.239 *$ & 0.040 & $-0.550 *$ & 0.077 \\
\hline On welfare 10 years or more & $0.202 *$ & 0.057 & $-0.650 *$ & 0.124 \\
\hline Number of children & $0.092 *$ & 0.012 & $0.100 *$ & 0.021 \\
\hline Number of children under age 6 & -0.027 & 0.027 & -0.008 & 0.043 \\
\hline Age of youngest child & $0.196 *$ & 0.021 & $0.090 *$ & 0.035 \\
\hline Age of youngest child squared & $-0.0076 *$ & 0.0010 & -0.0033 & 0.0017 \\
\hline Age of youngest child less than 1 & $-0.807 *$ & 0.078 & $-0.937 *$ & 0.126 \\
\hline Age of youngest child at least 1 , under 3 & $-0.405 *$ & 0.052 & $-0.360 *$ & 0.084 \\
\hline High school graduate & $-0.342 *$ & 0.025 & $-0.280 *$ & 0.042 \\
\hline Quarters with earnings in last year & $-0.201 *$ & 0.072 & -0.027 & 0.117 \\
\hline No work in last year & $-0.243 *$ & 0.043 & -0.135 & 0.072 \\
\hline Earnings in last year & $-0.000030 *$ & 0.000006 & -0.000010 & 0.000009 \\
\hline Quarters with earnings in prior 4 years & $-0.170 *$ & 0.078 & $-0.339 *$ & 0.126 \\
\hline No work in prior 4 years & -0.103 & -0.103 & -0.115 & 0.063 \\
\hline Earnings in prior 4 years & $-0.000004 *$ & 0.000002 & -0.000001 & 0.000003 \\
\hline St. Louis City & $-1.005 *$ & 0.044 & $-1.297 *$ & 0.081 \\
\hline St. Louis County & $-0.840 *$ & 0.048 & $-1.056 *$ & 0.089 \\
\hline Suburban St. Louis counties & 0.052 & 0.052 & 0.149 & 0.076 \\
\hline Jackson County & $-0.091 *$ & 0.039 & -0.106 & 0.062 \\
\hline Suburban Kansas City counties & $0.231 *$ & 0.072 & $0.260 *$ & 0.103 \\
\hline Small metropolitan counties & $0.092 *$ & 0.042 & 0.058 & 0.065 \\
\hline Non-metropolitan counties (omitted) & - & - & - & - \\
\hline Dummies for month & \multicolumn{2}{|c|}{ Controlled } & \multicolumn{2}{|c|}{ Controlled } \\
\hline Likelihood ratio index & \multicolumn{2}{|c|}{0.1114} & \multicolumn{2}{|c|}{0.1094} \\
\hline Months of receipt & \multicolumn{2}{|c|}{482,876} & \multicolumn{2}{|c|}{346,910} \\
\hline Recipients & \multicolumn{2}{|c|}{66,330} & \multicolumn{2}{|c|}{56,984} \\
\hline
\end{tabular}

* Statistically significant at the 0.05 level, two-tailed. 
TABLE 3

Impact of Race on Sanction by Geographic Area:

Binomial Logit Predicting Sanction and Initiation of Sanction

\begin{tabular}{|c|c|c|c|c|}
\hline & \multicolumn{2}{|c|}{ Sanction } & \multicolumn{2}{|c|}{ Initiation of Sanction } \\
\hline & $\begin{array}{c}\text { Impact of } \\
\text { Race } \\
\end{array}$ & $\begin{array}{c}\text { Standard } \\
\text { Error }\end{array}$ & $\begin{array}{c}\text { Impact of } \\
\text { Race }\end{array}$ & $\begin{array}{c}\text { Standard } \\
\text { Error }\end{array}$ \\
\hline \multicolumn{5}{|l|}{ Independent Variables } \\
\hline St. Louis City & $-0.2769 *$ & 0.0956 & -0.4219 & 0.2223 \\
\hline St. Louis County & -0.0960 & 0.0921 & -0.2831 & 0.1937 \\
\hline Suburban St. Louis counties & -0.0161 & 0.1612 & 0.3159 & 0.2747 \\
\hline Jackson County & $-0.4041 *$ & 0.0607 & -0.1211 & 0.0932 \\
\hline Suburban Kansas City counties & -0.3587 & 0.2112 & -0.0652 & 0.3343 \\
\hline Small metropolitican counties & -0.1351 & 0.0941 & -0.0837 & 0.1485 \\
\hline Non-metropolitan counties & $-0.3730 *$ & 0.0571 & $-0.3487 *$ & 0.0872 \\
\hline
\end{tabular}

Sample and model specification: As in table 2.

* Statistically significant at the 0.05 level, two-tailed. 
TABLE 4

Relationship of County-Level Measures to Likelihood of Sanction

\begin{tabular}{|c|c|c|c|c|c|c|}
\hline \multirow[b]{2}{*}{$\begin{array}{l}\text { Independent } \\
\text { Variable }\end{array}$} & & & \multicolumn{2}{|c|}{ Sanction } & \multicolumn{2}{|c|}{ Initiation of Sanction } \\
\hline & & & Coefficient & $\begin{array}{c}\text { Standard } \\
\text { Error }\end{array}$ & Coefficient & $\begin{array}{c}\text { Standard } \\
\text { Error }\end{array}$ \\
\hline \multirow{3}{*}{$\begin{array}{l}\text { Percent of county } \\
\text { population } \\
\text { nonwhite }\end{array}$} & Linear & $\mathrm{X}$ & -0.0067 & 0.0049 & $-0.0134 *$ & 0.0050 \\
\hline & \multirow{2}{*}{ Quadratic } & $X$ & 0.0183 & 0.0119 & 0.0145 & 0.0127 \\
\hline & & $X^{2}$ & $-0.0006 *$ & 0.0002 & $-0.0006 *$ & 0.0003 \\
\hline \multirow{3}{*}{$\begin{array}{l}\text { Percent of county } \\
\text { officials } \\
\text { Democratic }\end{array}$} & Linear & $\mathrm{X}$ & 0.0008 & 0.0011 & 0.0015 & 0.0013 \\
\hline & \multirow{2}{*}{ Quadratic } & $X$ & 0.0024 & 0.0051 & 0.0054 & 0.0059 \\
\hline & & $X^{2}$ & -0.00001 & 0.00005 & -0.00004 & 0.00005 \\
\hline \multirow{3}{*}{$\begin{array}{l}\text { Percent Senate } \\
\text { vote Democratic }\end{array}$} & Linear & $X$ & -0.0036 & 0.0061 & -0.0050 & 0.0068 \\
\hline & \multirow{2}{*}{ Quadratic } & $\mathrm{X}$ & $0.1446 *$ & 0.0435 & $0.1708 *$ & 0.0471 \\
\hline & & $X^{2}$ & $-0.0017 *$ & 0.0005 & $-0.0020 *$ & 0.0005 \\
\hline \multirow{3}{*}{$\begin{array}{l}\text { Unemployment } \\
\text { rate (percent) }\end{array}$} & Linear & $\mathrm{X}$ & -0.0136 & 0.0223 & -0.0414 & 0.2570 \\
\hline & \multirow{2}{*}{ Quadratic } & $X$ & -0.0225 & 0.1018 & 0.0342 & 0.1171 \\
\hline & & $X^{2}$ & 0.0008 & 0.0087 & -0.0067 & 0.0101 \\
\hline \multirow{3}{*}{$\begin{array}{l}\text { TANF caseload } \\
\text { as percent of } \\
\text { population }\end{array}$} & Linear & $\mathrm{X}$ & -0.1196 & 0.0845 & $-0.1977 *$ & 0.0894 \\
\hline & \multirow{2}{*}{ Quadratic } & $\mathrm{X}$ & 0.1609 & 0.2431 & 0.2627 & 0.2674 \\
\hline & & $X^{2}$ & -0.1049 & 0.8496 & $-0.1663 *$ & 0.0910 \\
\hline \multirow{3}{*}{$\begin{array}{l}\text { Percent of } \\
\text { caseload } \\
\text { nonwhite }\end{array}$} & Linear & $\mathrm{X}$ & -0.0014 & 0.0021 & $-0.0045 *$ & 0.0022 \\
\hline & Oundrotio & $\mathrm{X}$ & $0.0178 *$ & 0.0058 & $0.0183 *$ & 0.0062 \\
\hline & Quadratıc & $X^{2}$ & $-0.0003 *$ & 0.0001 & $-0.0003 *$ & 0.0001 \\
\hline Sample size & & & \multicolumn{2}{|c|}{115} & \multicolumn{2}{|c|}{114} \\
\hline
\end{tabular}

*Significant at the 0.05 level, one-tailed. 
Figure 1: Percent of County Nonwhite and Initiation of Sanction

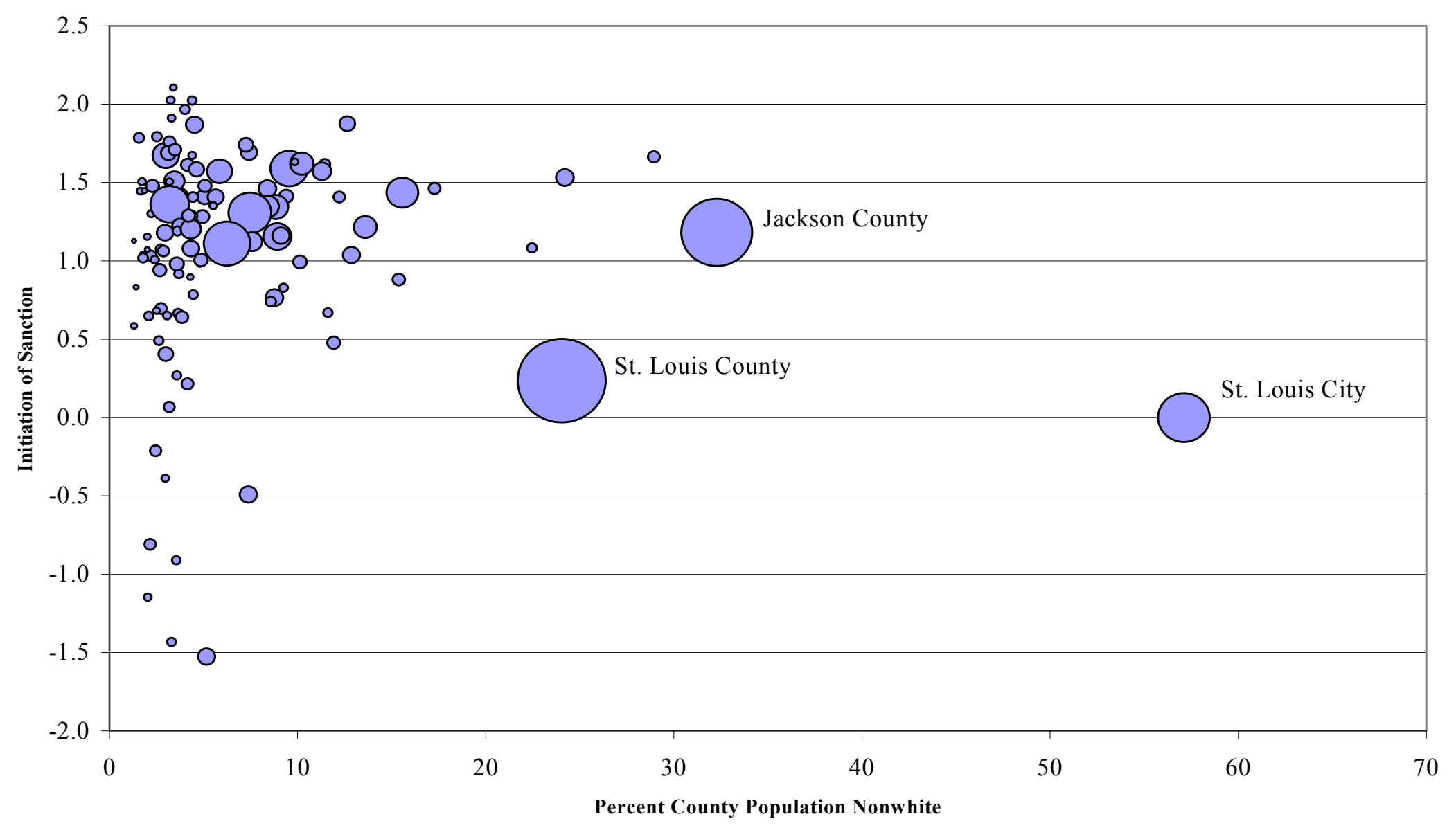

